\title{
The current situation and solutions of effective university governance in Vietnamese public higher education institutions
}

\author{
Bui Quang Hung ${ }^{1 *}$, Pham Quang Huy ${ }^{1}$, Luong Duc Thuan ${ }^{1}$, Vu Minh $\mathrm{Ha}^{1}$, Dao Thi Minh Huyen ${ }^{1}$ \\ ${ }^{1}$ University of Economics Ho Chi Minh City, Vietnam \\ *Corresponding author: bqhung@ueh.edu.vn
}

\begin{abstract}
ARTICLE INFO
ABSTRACT

DOI: 10.46223/HCMCOUJS.

econ.en.12.1.1900.2022

Received: May $28^{\text {th }}, 2021$

Revised: June $03^{\text {rd }}, 2021$

Accepted: August $06^{\text {th }}, 2021$

Keywords:

higher education institution; public university autonomy; university governance

The main research objective of this paper is to study the current situation and solutions of effective university governance in public Higher Education Institutions (PHEIs) in Vietnam in the direction of autonomy. The paper uses a method that combines qualitative and quantitative research to analyze theoretical basis and related background theories and assess the current state of university governance in Vietnam. With quantitative research, method is done in the form of online surveys through questionnaires. The topic of the questionnaire focuses on collecting comments on governance activities being carried out at the PHEIs of Vietnam in an autonomous direction. The research results have shown quite clearly the contents related to the issues of governance and administration in the PHEIs, the way of managing and evaluating the performance of the PHEIs. Since then, the authors have proposed a number of groups of solutions for effective university governance at Vietnam's PHEIs in the direction of autonomy. The solutions and proposals will be the necessary and important practical foundation to innovate and develop policies to promote university autonomy for sustainable and efficient development.
\end{abstract}

\section{Introduction}

In the current context of globalization and integration, world higher education is in a period of strong transformation. In this context, a country that lags in reforming the higher education system, especially in renovating its views and higher education management mechanism, will completely lose the opportunity for economic integration and development. To achieve this goal, it is necessary to have an appropriate policy mechanism to promote a breakthrough in synchronous reform of the policy system in general and education in particular.

University governance is being considered as an important issue affecting the development of universities in order to achieve the goal of increasing effectiveness and effectively applying management tools on the basis of building control all activities independently, autonomously, clearly and transparently delineate the responsibilities of objects in the organization. To do so, the school needs to set strict standards and criteria to evaluate the performance of tasks, autonomy, and self-responsibility of subjects in finance, infrastructure, implementing the principle of improving quality in management, training, scientific research, etc. Along with that, ensuring financial transparency while operating processes. The factors of globalization, the progress and development of science and technology, the efforts to apply the market mechanism in Vietnam are 
putting universities in a constantly changing operating environment, so it requires asked schools to reduce cumbersome and time-consuming management procedures to adapt to the rapid changes of the economy and market.

University autonomy is currently a global trend in higher education administration, an inevitable trend of countries in university governance, which is the tendency to reduce state intervention in school management strengthening the autonomy for schools. The Party and State have always cared and tried to create a legal corridor for the autonomy of higher education institutions. Although the piloting to allow some universities to be autonomous has helped these human resource training institutions begin to have many positive changes, the existing universities have not yet achieved the results as expected. Therefore, it is still necessary to continue the practice and innovate to promote this mechanism in the coming time. This article is conducted to understand the current situation and propose solutions for efficient university governance at higher education institutions in Vietnam in the direction of autonomy.

In terms of science, the research is expected to supplement scientific awareness, theory, and methodology on higher education administration in international integration. This is shown through the synthesis and analysis of theoretical perspectives, the theoretical basis for effective university governance at higher education institutions in the direction of autonomy.

In terms of practice, research on the current situation combined with actual surveys on university governance activities at higher education institutions in Vietnam towards autonomy, thereby proposing a few solutions for effective university governance at Vietnamese higher education institutions in the direction of autonomy. Solutions and proposals will be necessary and important practical arguments to innovate and develop policies to promote university autonomy for sustainable and efficient development.

\section{Literature review}

\subsection{An overview of university governance in the public sector}

\subsubsection{Overview of governance in public higher education institutions}

Good governance in PHEIs can be explained as the implementation of the basic principles of "good governance" in the system and process of governance at a higher education institution. Implementation is carried out by adapting those principles to the value of having to be highly respected in education. Based on developing education, academic knowledge, and developing the whole person. Tilaar (2012) argues that there are differences and similarities between higher education institutions and the business world. The similarities are in terms of efficiency and feasibility. Both are expected to deliver qualified results. Meanwhile, the difference lies in the vision and mission, in which for higher education, the agent is professor, student and science; knowledge is an object.

The importance of implementing governance in PHEIs is often laid out in the future. Good organizational governance can bridge the gap to better higher education because principles and practices are already in place. On the other hand, there are sizable differences between education, government, and business. The model of change towards higher education with good governance is made with the need to adapt to the changes of the world. During this change, higher education remains focused on its traditional mission of teaching, learning, and research. Today, society demands more from universities in terms of their contribution. Therefore, universities should move from adaptive knowledge generation to integrated knowledge generation and become learning organizations (Bratianu, 2014; Senge, 1999). This means that if governance becomes the strategic 
driver of the university and is a powerful integrator, it can effectively convert potential knowledge capital into operational knowledge capital (Bratianu, 2014). Organizing a higher education institution cannot be equated with organizing a state or an enterprise. There are paths to honor, both academic and social, that need to be maintained. Meanwhile, other paths should be seen as means or tools to achieve those primary goals.

\subsubsection{Principles of effective governance in public higher education institutions}

These governance principles are implemented to support the function and goals of higher education. The educational, teaching, and research functions reflect the role of higher education in society. A study by Bratianu and Pinzaru (2015) explains that the implementation of reasonable governance in higher education is the strategic driver supporting to achievement the vision, mission of higher education. Principles of good governance can be used as a reference for a legitimate educational institution, including the following 09 principles:

(1) Autonomy, authority, and ability to conduct activities independently in both academic and non-academic fields;

(2) Accountability, which is the ability and commitment to be responsible for all activities of the educational, legal entity to related parties in accordance with current law;

(3) Transparency, which is the openness and ability to provide relevant and accurate information in a timely manner, in accordance with applicable law and reporting standards to stakeholders;

(4) Quality assurance, which is systematic activities to serve formal education that meets or exceeds national educational standards, and at the same time improves the quality of education sustainably;

(5) Excellence service is the orientation and commitment to providing the best formal education service to the satisfaction of students as key stakeholders;

(6) An equal access, which is the provision of formal education services to prospective and current students, regardless of religion, race, ethnicity, sex, social and economic status;

(7) Diversity, which is the sensitivity and adaptive attitude to differences in interests based on religious, racial, ethnic, and cultural peculiarities;

(8) Sustainability is the ability to provide formal education services to students continuously with a management model capable of ensuring sustainable services;

(9) The participation and responsibility of the State, which is the participation of stakeholders in the conduct of formal education to improve the quality of the nation's intellectual life, is the responsibility of the State.

The parties involved in the implementation of university governance are representatives of stakeholders, educators, independent auditors, internal auditors, and educational administrators (Warsono, 2009). To monitor the implementation of good governance in PHEIs, a series of assessments is required. One of the models developed is a ranking model and can be a standard for evaluating good governance in PHEIs. The results of such assessments are expected to serve as benchmarks that can be used as inputs for the improvement of relevant higher education.

\subsection{Background theories}

\subsubsection{Agency theory}

Agency theory, also known as owner-agent model theory, describes the relationship 
between two or more parties, in which one party is designated as the owner, participating with the other party, appointed as an agent, or manager, to perform some work on behalf of the owner (Jensen \& Meckling, 1976; Moe, 1984). Agency theory is one of the most widely used theories in management or administration. More specifically, it looks at this relationship from a behavioral and structural point of view. This theory holds that if given the opportunity, the agent will behave in a favorable way, behavior that may conflict with the interests of the owner (Jensen \& Meckling, 1976; Wiseman, Cuevas-Rodríguez, \& Gomez-Mejia, 2012). Therefore, the owner needs to enact structural mechanisms to help monitor the agent to limit opportunistic behavior and better align the parties' interests (Cruz, Gómez-Mejia, \& Becerra, 2010; Eisenhardt, 1989).

Agency theory, in the form of a neo-liberal theory, is found to be suitable for providing insight into the radical transformation of the public sector, including higher education institutions (Olssen \& Peters 2005). Althaus (1997) also observes that agency theory is at the heart of the powerful reforms that have taken place in many countries with the aim of maximizing economic efficiency, leading to policies of deregulation, focus unionization, and privatization.

\subsubsection{Institutional theory}

Institutional theory has become a popular and powerful tool for explaining the actions of both individual and collective actors. It emphasizes the institutional dependence of action by actors and on the role of self-determination in institutional change (Greenwood, Raynard, Kodeih, Micelotta, \& Lounsbury, 2011). One trend in this area is to conduct institutional analysis in a complex institutional environment (Greenwood et al., 2011; Thornton, Ocasio, \& Lounsbury, 2015).

This theory is said to have become a popular and powerful explanatory tool for the study of various organizational problems, including those in the context of higher education. University administrators and elected officials seek legitimacy with voters. One way to achieve legitimacy is for these parties to engage in self-improvement to demonstrate their willingness to serve the needs of the public. From the university's perspective, in the quest for legitimacy, public actions in the form of restructuring events are widely publicized. On the other hand, non-public activities among administrators, lecturers, and students help the organization carry out its day-to-day activities.

\subsubsection{Management theory}

Management theory also deals with the working relationship between two parties, the owner and the manager (Davis, Schoorman, \& Donaldson, 1997). This theory also considers the relationship from a behavioral and structural perspective. This theory assumes that managers will behave in a manner, behavior for the common good of society that is directed towards the interests of the owners and, therefore, the interests of the organization (Zahra, Gedajlovic, Neubaum, \& Shulman, 2009). This behavior is motivated by the character of the relationship between owners and managers and between the environment and the organization's ideals (Corbetta \& Salvato, 2004).

Based on the argument of Manz (1986), it can be argued that managerial relationships are applicable in a culture of educational autonomy of higher education, which is characterized by a high degree of self-motivation which is valued in the activities of universities. Eisenhardt (1989) agrees with this, arguing that managers in managerial relationships need their own authoritative autonomy to creatively fulfill their job expectations and achieve success in the organization. Along with the recognition in public administration systems that an individual is motivated to act by financial gain and is also motivated to act in response to a need for self-expression.

\subsection{Analytical framework}

From the process of analyzing the principles of governance in PHEIs, it can be seen that the 
issue of autonomy has a very important role in governance at the current PHEIs in Viet Nam. Autonomy will give schools sufficient authority to conduct academic and non-academic activities. Autonomy also helps schools to be more transparent and accountable in all matters, schools will represent the state to perform more professionally on issues in the field of education, and schools will also be more self-determined in implementing and changing operating institutions but still ensure compliance with state management regulations and that helps PHEIs to ensure that they always act in the interests and common goals of society, owners and organizations. Thus, the authors believe that from the analysis of governance issues of PHEIs together with three related background theories, it is possible to fully and reliably assess the current situation at PHEIs in Vietnam.

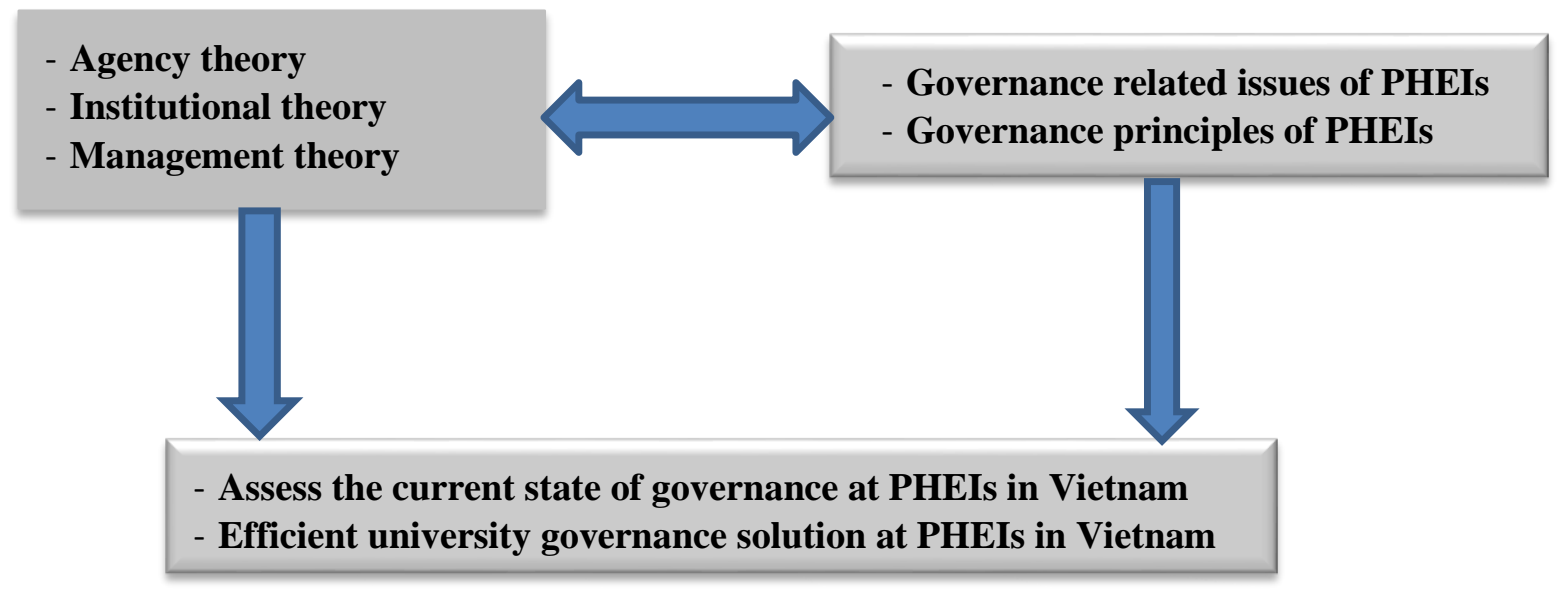

Figure 1. Analytical framework

\section{Research methods}

\subsection{Research process}

The research process is a series of actions and takes place in a certain sequence and is associated with the knowledge base as well as logical thinking steps. Defining the process makes it easier for the authors to conduct research related to a topic and to address the stated objectives:

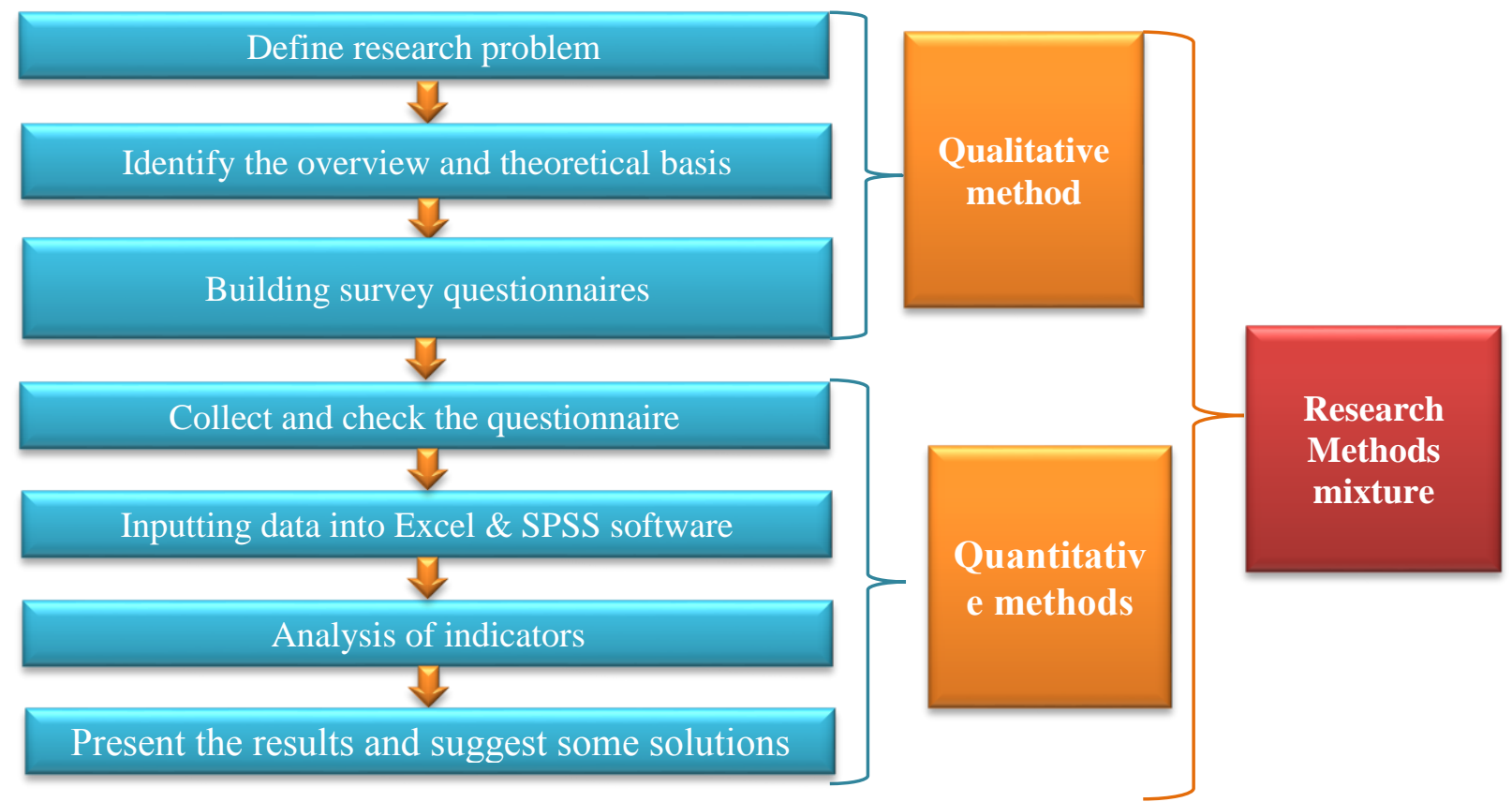

Figure 2. Research framework process of the topic

Source: Proposal of the author's team 


\subsection{Applied research methods}

The research paper uses a mixed-method, a combination of qualitative and quantitative research methods, and presents the content of research results on the basis of descriptive statistics. As follows:

\subsubsection{Qualitative research methods}

Qualitative research is a process that helps the authors form an awareness of the importance of the main contents of the survey process in terms of what needs to be implemented at higher education institutions, that is, university governance for fully autonomous universities. First, the authors used qualitative research methods such as reading and researching to synthesize domestic and foreign research data and documents on autonomous schools in terms of governance.

Next, the topic also deployed the consultation of experts at the schools on determining the relevant theoretical basis as well as statements in each of the different topics being surveyed, the basis for building statements about the status, governance models. Therefore, with this method, the author has used methods of collecting, classifying, synthesizing, processing, and analyzing. In which the author reads and synthesizes previous studies to form the content of interviews with experts. After that, the author collects secondary data and analyzes it to reflect the current state of governance in schools when evaluating school governance performance. Since then, the topic will summarize the results of quantitative research to serve as a basis to increase the reliability of the research results and the basis of recommendations.

\subsubsection{Quantitative research methods}

Quantitative research methods mainly focus on analyzing survey questionnaires on Microsoft Excel 2016 and SPSS 22 software. After coding, the data are screened and selected for input into the system for analysis. The collected data outputs are mainly descriptive statistics by using methods of comparing, deducting, and synthesizing the contents between the theoretical system and the practice to identify and evaluate the advantages, limitations, and causes of some limitations or recognition of the successes of current governance measures in Public Higher Education Institutions (PHEIs).

\subsection{Data for research and sampling method}

Government (2014) has issued Resolution 77/NQ dated October 24, 2014 on piloting innovation of operation mechanism for PHEIs in the period 2014 - 2017. Since the introduction of this legal document until now, the pilot model of the autonomy mechanism at PHEIs has obtained a lot of positive results in the first step. Reports from many schools have shown remarkable results when applying state-affirmed and recognized autonomy. By the end of 2019, a total of 23 universities out of a total of more than 235 schools across the country are allowed to pilot autonomously, and the tuition fee will be doubled to 3.5 times higher than universities that have not yet implemented autonomy. The detailed list of the 23 universities mentioned above is specifically listed as follows:

1. Hanoi University;

2. Ton Duc Thang University;

3. Ho Chi Minh City Open University;

4. University of Finance - Marketing;

5. University of Economics Ho Chi Minh City; 
6. Foreign Trade University;

7. National Economics University;

8. Vietnam Academy of Agriculture;

9. Industrial University of Ho Chi Minh City;

10. Academy of Post and Telecommunications Technology;

11. Electricity University;

12. Hanoi University of Textile Industry;

13. Ho Chi Minh City University of Food Industry;

14. University of Commerce;

15. Hanoi University of Science and Technology;

16. University of Economics, University of Danang;

17. Ho Chi Minh City University of Law;

18. Tra Vinh University;

19. University of Economics - Industrial Technology;

20. Can Tho University of Medicine and Pharmacy;

21. Ho Chi Minh City University of Technology and Education;

22. Hanoi Open University;

23. Hanoi University of Industry.

The survey process is implemented by the author team in the form of an online survey in the form of a link at Google Form. The questionnaire focused on asking for opinions on governance activities being carried out at universities in the direction of autonomy.

After designing the research framework and obtaining an overview of related research theories, the authors collect research data through questionnaires. The questionnaire is designed by the author with statements in affirmative sentences; each sentence has 05 options (1. Very bad; 2. Not good; 3. Average; 4. Good; 5. Very good) respondents selected only one option. This is a question to achieve a certain clarity about an idea, a single conclusion about a specific problem to be explored through the mind of the surveyed person. This is a type of question to assess according to the nature of the respondent's behavior based on the respondent's perception and understanding of a particular statement related to the research topic.

Going into the details of the content of the questionnaire, the research structure is divided into 02 main parts, in which the first part is general information about demographics and the second part is related to the main content of the topic.

- General information includes the respondent's unit, current position, management time, type of autonomy of the unit, and organizational structure of the internal audit and control team;

- The detailed information section is presented on university governance. The form of the question is a 5-level Likert scale, Yes/No questions, along with multiple-choice questions to collect respondents' views on the status of university governance at the institution.

\section{Research results and discussion}

University governance is the process of building and gathering rules and systems to 
manage and control the entire operation of a university. The university administrator will be accountable to the school, community, and learners for the reliability, adaptability and costeffectiveness of administration through the division of responsibilities, resources and effective control and efficiency. The functions of university administration involve the following activities: Planning, organizing, leading, and controlling for different levels of governance. University autonomy is considered a fundamental issue of university governance and an inevitable issue of the current universities in Vietnam. Through the process of collecting data from 20/23 (87\%) universities include non-business units that cover recurrent expenditures and recurrent and investment units. Most of the respondents in the survey were the head and deputy head of the financial planning department of the university. They had 10 to 15 years of working experience, accounting for the most $40 \%$. It shows that they have enough knowledge and experience in management related to the administrative and financial issues of the unit. Therefore, the information collected by the survey team from these subjects has high reliability and is completely suitable for statistics and data analysis. The research team summarized the results of the analysis of survey data on university governance according to the following contents:

\subsection{General management and administration issues in public higher education institutions}

In order to implement effective governance and administration at PHEIs, the first issue the research team considers is that the governance and management at these units are managed with key subjects in the management agency of the PHEIs, according to which there are 10 schools being managed by the Board of Directors (rate of 50\%), the second object represented in the governing body of the PHEIs is the lecturers (rate of 40\%) and the third object represented in the governing body of PHEIs is the stakeholders including students, alumni, partners, government and the public (rate of $35 \%$ ).

In addition, to effectively manage of PHEIs, it is necessary to have the most basic and general principles in the management process. Accordingly, most respondents said that the basic and most important principle of effective PHEIs management is "Quality assurance / effective service" with 19/20 respondents accounting for 95\%. The second important principle is "Transparency in information presentation and decision making," with 18/20 respondents, accounting for $90 \%$. The third important principle is "Autonomy in carrying out academic and non-academic activities" with $16 / 20$ respondents, accounting for $80 \%$. In addition, the principle of management of PHEIs has the lowest rate of $45 \%$ related to "State responsibility and participation".

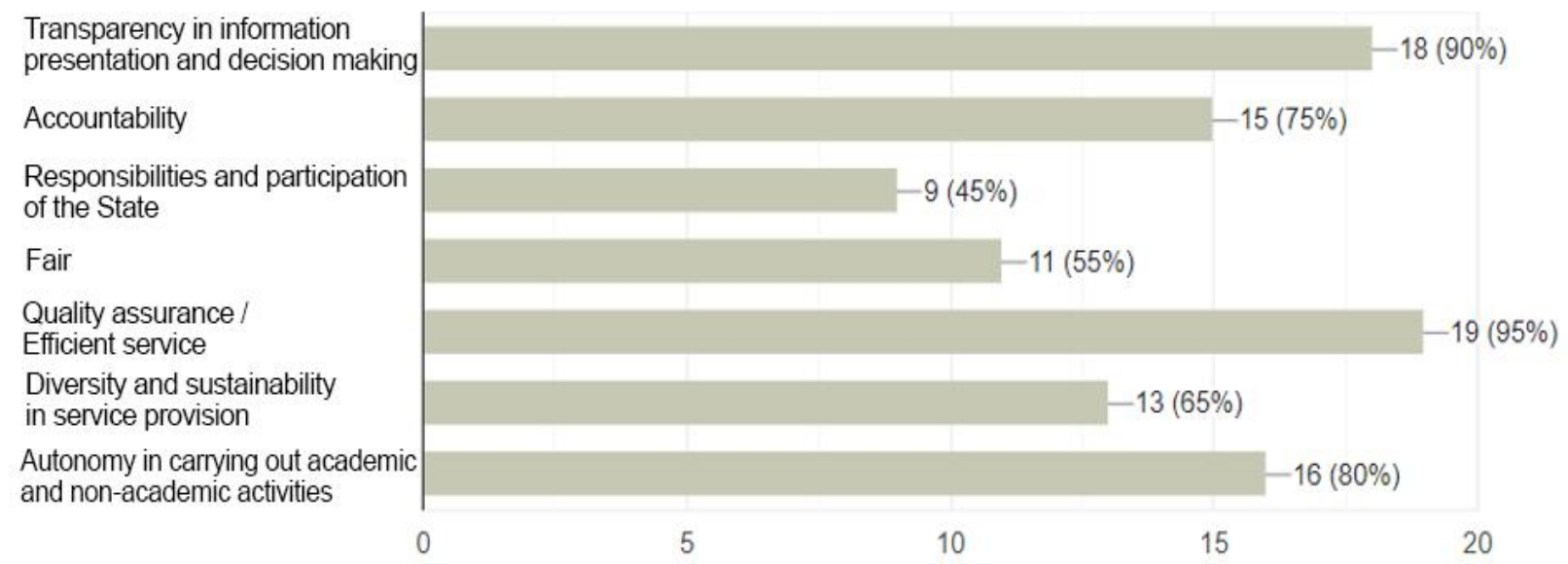

Figure 3. Principles of PHEIs governance 


\subsection{Evaluation of performance and management methods in public higher education institutions}

In order to carry out performance evaluation in the unit, it is essential to establish key performance indicators to serve the management and monitor the success in achieving the objectives. With the survey results, $85 \%$ of the units responded that they had established performance indicators, showing that the units are also quite focused on the management and supervision of activities at their units. It shows that, in management activities, the units have built strategic goals operational goals and evaluated the goals through established indicators, from which there are evaluations and review the successful or unsuccessful activities of the unit to have more complete solutions in the future.

In the current PHEIs, which are quite large in scale and decentralized, these units have a diverse organizational structure, including many management departments, many faculties, departments, and many other participating lecturers together. Therefore, the performance evaluation process can be carried out at different levels depending on the characteristics and evaluation objectives of each school. In general, the assessment of the performance is being carried out mainly for the whole school, each department, each faculty, and each lecturer, with the rate from $75 \%$ to $90 \%$. The assessment of performance for subject levels in schools is still limited (55\% rate).

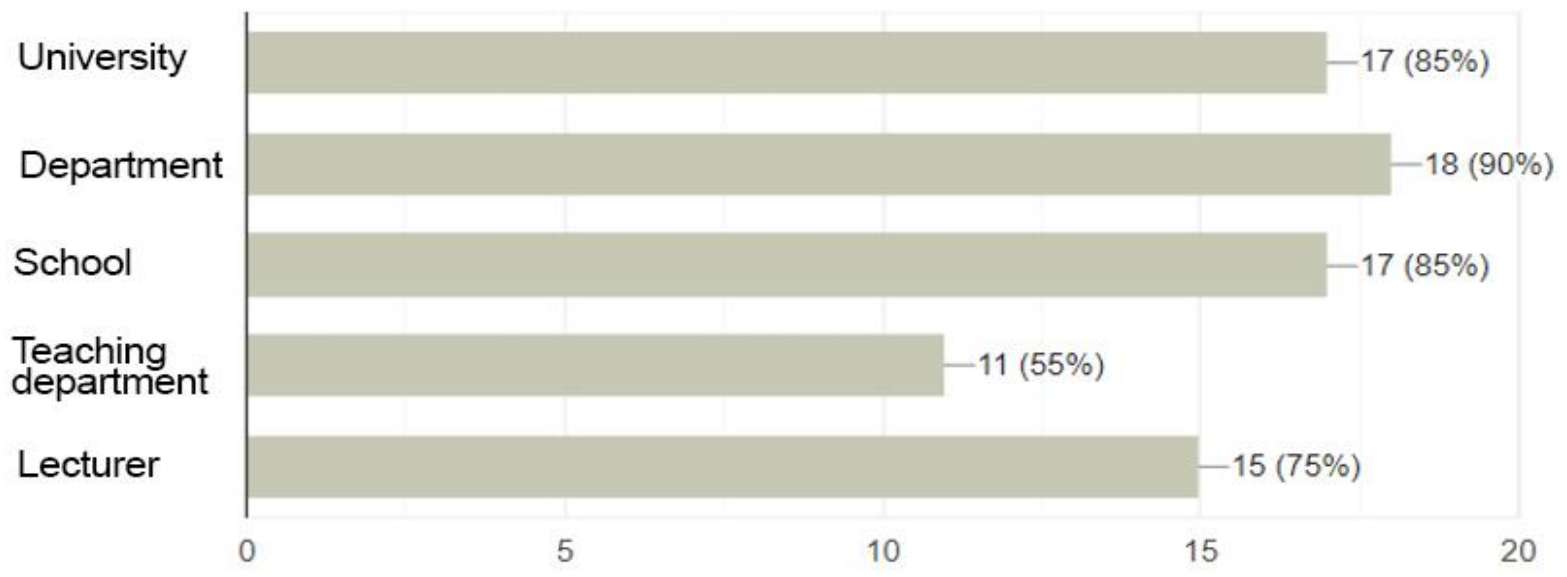

Figure 4. Subjects needing performance assessment in public higher education institutions

There are many aspects related to the assessment of management in the governance of PHEIs; units need to clearly define important aspects and key contents in unit management. Accordingly, there are 03 aspects that are most concerned by the units when assessing the management of PHEIs: enrollment, training programs, and facilities with the rate of $90 \%$. Aspects that are of secondary concern to the units when evaluating management are: (1) attracting and retaining lecturer/staff, (2) optimizing spending, (3) improving quality of living, (4) student support services, accounting for $80 \%$. The third aspect of interest, accounting for $75 \%$, is to enhance the academic activities of the lecturers. The fourth aspect of concern in management assessment concerns graduates with a rate of $70 \%$. The fifth aspect of concern of the units in the management assessment is related to the issue of enhancing funding sources and serving the community with a rate of $65 \%$. 


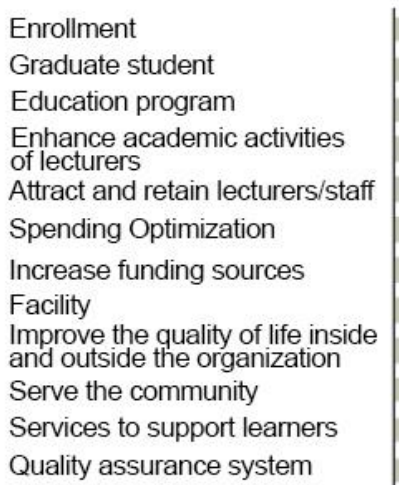

Quality assurance system

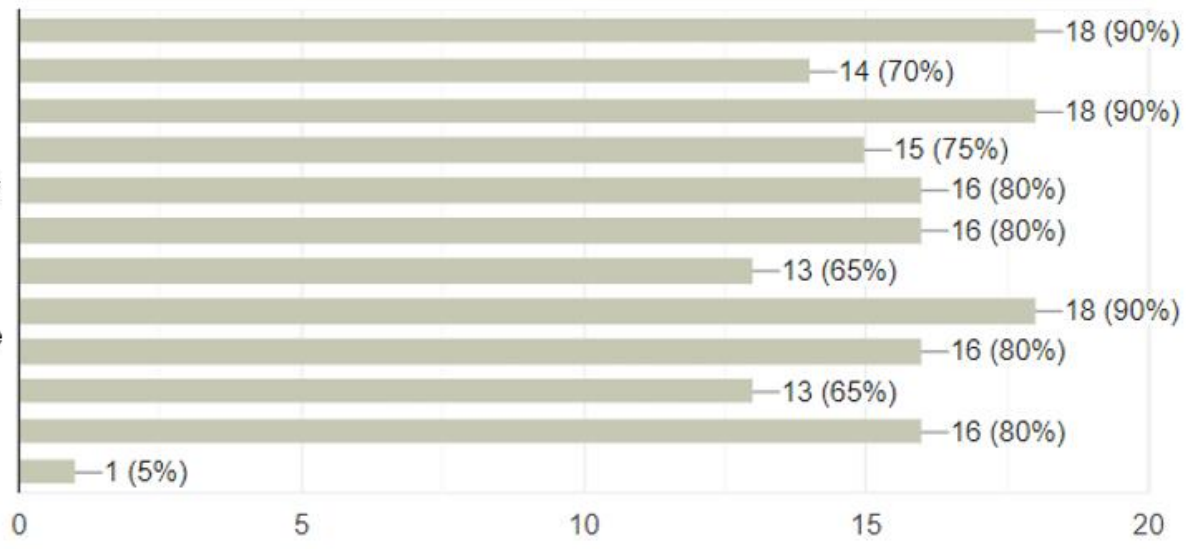

20

Figure 5. Aspects of management assessment in the governance of public higher education institutions

They are relating to the management of the work performed for officials and managers in the current PHEIs. Most schools stipulate that teaching staff, administrators self-assess, and students are the object of evaluation of teaching staff, administrators with high rates of $85 \%$ and $80 \%$, respectively. Evaluation from external partners (enterprises, employers, alumni) of teaching staff and administrators is still quite limited, with few schools still paying attention to this issue. The percentage, according to the survey results, is $30 \%$.

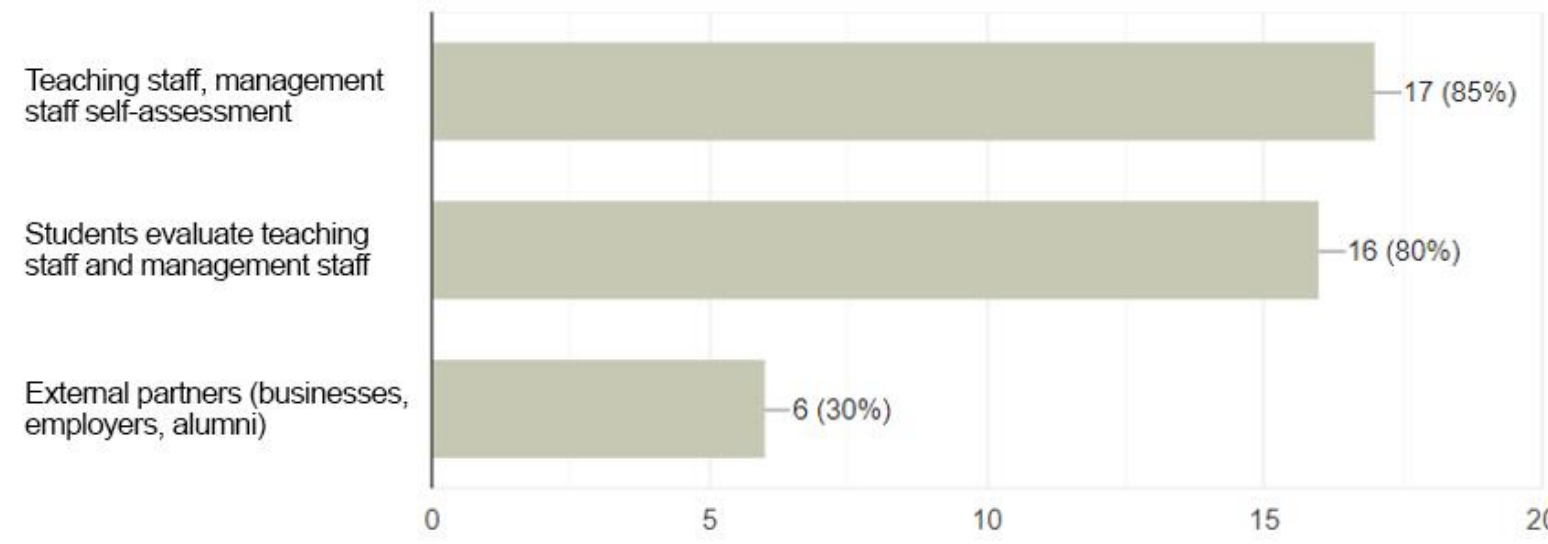

Figure 6. Performance evaluation for officials and managers in public higher education institutions

There are many management methods applied in evaluating the effectiveness of management work at PHEIs. According to the survey results, $85 \%$ of the units choose the management method as "Organizing responsibility centers by unit," and $65 \%$ of the units choose the management method as "Organizing the responsibility centers for each job/task." In which, many units choose both of these management methods in the process of evaluating work efficiency at the unit. Regarding the method of evaluating management effectiveness, most schools choose the evaluation method based on the "Set of evaluation and ranking criteria", with the rate of $70 \%$, and the second is the evaluation method according to "Key Performance Indicators (KPIs) with the rate of $50 \%$. Other assessment methods are also applied by some schools but account for a very small percentage. 


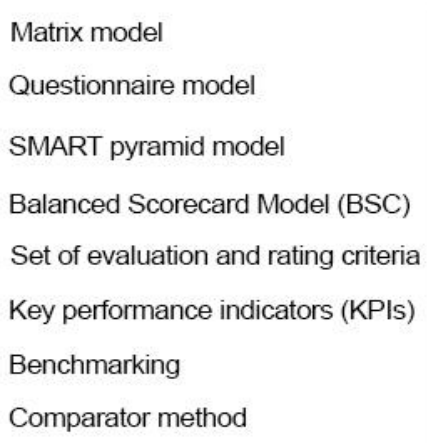

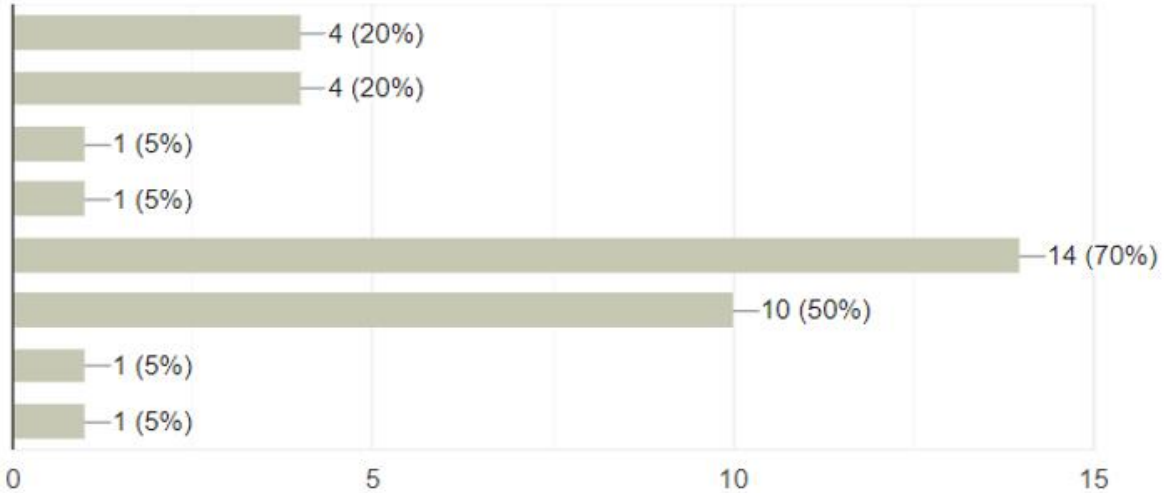

5

10

15

Figure 7. Methods of evaluating management effectiveness in public higher education institutions

They are relating to the assessment of the current state of governance in PHEIs. According to the survey results with 12 evaluation criteria proposed by the research team, all criteria have an average value of over 3.50. Thus, the performance evaluation of governance in PHEs is currently quite good, in which, there are 04 criteria evaluated by the units with the Average Score (AS) greater than 4, including:

- Academic activities (Enrollment, student, graduation, study programs, study support, quality improvement: AS 4.40;

- Teaching activities (Teaching and academic administration, scientific research, internationally published articles, training quality accreditation, etc.): AS 4.30;

- Mission, vision, goals and cultural values: AS 4.30;

- Finance (Optimizing spending, increasing revenue): AS 4.05.

\section{Conclusions and suggestions}

\subsection{Some solutions for effective university administration}

When schools are fully autonomous in their operation, it is an opportunity to improve the quality of training. In essence, autonomy in a PHEI is mainly concerned with financial autonomy and training autonomy. Since then, for these two aspects to be implemented consistently and effectively, solutions related to management and administration in the unit are the foundation for the two jobs to be successful create a strong bounce for the overall development of the whole unit.

5.1.1. Comprehensive assessment of the legal system and management mechanism of public higher education institutions

PHEIs need to have an overall review of all aspects of management to properly resolve the relationship between the autonomy process and the relationship between the three activities, including leadership, governance, and university management. From there, clarify the roles, positions, powers, duties as well as the relationship between the three main institutions, namely the Party Committee, the school council, and the Board of Management, to find detailed solutions to the problems in the relationship in the direction of delegating real power to the School Council and operating it to the Board of management. To have university autonomy, the legal system must be synchronous, becoming a unified and highly dialectical whole that is both open, synchronous, and clear to help build and create a legal trust for the PHEIs as well as for society, avoiding the illusion that everything is legally regulated but not enforced or must be enforced in a different way as it is today. 


\subsubsection{Build control, governance, and decentralization mechanisms according to respective} resources

For the management process to be enforceable and effective, schools need to build for themselves an effective control and assignment mechanism as well as integrate many inspection activities and check independently. In addition, these mechanisms also need to be associated with the functions, duties, and responsibilities of individuals, avoiding the phenomenon of not specifying the responsibility of each specific object in the school when setting up work in managing different stages to operate the policy of autonomy. Specifically, the school should consider setting strict standards and criteria related to each specific aspect of governance to evaluate the performance of the task, showing the nature of the implementation process autonomy, self-responsibility of subjects in areas such as teaching, scientific research, human resources, facilities, finance, learners and at the same time will implement the principle of regime supervision in management, at work, in training, etc. at the same time, there is a mechanism to determine those criteria.

\subsubsection{Shaping standardized monitoring activities in public higher education institutions}

Solutions on management of supervision and inspection activities towards the quality management of training activities in universities. When it comes to autonomy, it can be understood that universities are active in many activities and responsible for the process of making relevant decisions, creating their own trust in the whole society, the element of accountability is enhanced. In this case, accountability is the school's responsibility to society. The university is not just a statement of commitments, ornate statements on documents or the media, but it is the responsibility of the school to parents, learners, users. employing workers, the public will accept the quintessential products that the school has trained.

\subsubsection{Solutions on university governance model in higher education institutions}

An important issue when operating management is that universities need to choose for themselves a suitable university governance model according to the mission, vision, core values and strategies of the organization. According to current regulations in Vietnam, this issue is the responsibility of the School Board. In addition, in terms of organization, the head of a PHEI is not elected by a collective of lecturers, officials or the council of that institution, but appointed or recognized by a competent state agency. These members will jointly review and apply a governance model that is independent, effective and is almost no longer subject to management by the respective superior agency. The change and selection of this model must be towards a model that ensures real executive power, adequate control mechanism as well as removing certain constraints in administrative management towards exploiting the effectiveness of strategy implementation; from there, the executive capacity of the management team will also have to be enhanced.

\subsection{Conclude}

Intending to study the current situation and solutions to university governance in the direction of full autonomy, the authors have researched and reviewed relevant previous studies, synthesized the basic theories of public administration, and have studied and researched related topics, university governance; as well as learn the theoretical bases, effective university management methods. Simultaneously, the research team has surveyed and collected information on the practice of governance at PHEIs in the direction of autonomy in Vietnam to evaluate and analyze the situation at autonomous universities in Vietnam. The survey results collected from 20 universities in the direction of autonomy in Vietnam made the following main conclusions:

Most of the current PHEIs are very interested in building the mission, vision and strategies, and goals in the management and operation of the unit. The reality of governance is also assessed 
by the units as being performed quite well in all aspects of operations, which shows that the units have been paying great attention in the evaluation of performance results in the field of all aspects of the operation. The units also identified some of the most important issues in governance, in which the focus was on the organization of the effective management apparatus, financial issues, and management mechanisms, operational control, and efficient use and allocation of resources. The areas of activity that are being paid the most attention by higher education institutions when evaluating management in the governance of PHEIs are enrollment, training programs, and facilities with the rate of $90 \%$. In general, the management and administration in the current PHEIs have made positive changes in line with the context and operating environment of the units. The units are interested in building the apparatus establishing the school council the board of directors with diverse members in many different positions and duties, including lecturers, alumni, businesses, and partners.

\subsection{Limitations of the research}

In addition to the obtained results, the study is not immune to certain limitations. Firstly, the s study sample is not highly representative of the opinions of all PHEIs in Vietnam. The selected sampling method is convenient, so the quality of the research sample is not high. Moreover, due to cost, time, and accessibility limitations, the sample size is not as large as expected. In addition, the cultural characteristics of Vietnamese people and the responsibility in answering questions are not high, leading to the obtained survey results, although meeting the statistical requirements, the authors still do not satisfy. In the future, if possible, further studies should expand the scope of the study increase the sample size to obtain more reliable results, but this requires the researcher to invest more time, effort, and cost.

\section{ACKNOWLEDGMENTS}

This article was conducted within the framework of the Ministerial level project at Code CT-2018-05-05.

\section{References}

Althaus, S. L. (1997). Computer- mediated communication in the university classroom: An experiment with on- line discussions. Communication Education, 46(3), 158-174.

Bratianu, C. (2014). Strategies to enhance intergenerational learning in universities. In Proceedings of the 11th International Conference on Intellectual Capital, Knowledge Management and Organizational Learning (pp. 83-90). Reading, UK: Academic Conferences and Publishing International.

Bratianu, C., \& Pinzaru, F. (2015). University governance as a strategic driving force. In Proceedings of the 11th European Conference on Management Leadership and Governance (pp. 28-35). Lisbon, Portugal: Military Academy.

Corbetta, G., \& Salvato, C. A. (2004). The board of directors in family firms: One size fits all? Family Business Review, 17(2), 119-134.

Cruz, C. C., Gómez-Mejia, L. R., \& Becerra, M. (2010). Perceptions of benevolence and the design of agency contracts: CEO-TMT relationships in family firms. Academy of Management Journal, 53(1), 69-89.

Davis, J. H., Schoorman, F. D., \& Donaldson, L. (1997). Toward a stewardship theory of management. Academy of Management Review, 22(1), 20-47. 
Eisenhardt, K. M. (1989). Agency theory: An assessment and review. Academy of Management Review, 14(1), 57-74.

Government. (2014). Nghị quyết số 77/NQ-CP ngày 24/10/2014 về thí điểm đổi mói co chế hoạt động đối với các co sở giáo dục đại học công lập giai đoạn 2014-2017 [Resolution No. 77/NQCP dated October 24, 2014 on piloting renovation of the operation mechanism of public tertiary education institutions during 2014-2017]. Retrieved April 10, 2021, from https://thuvienphapluat.vn/van-ban/Giao-duc/Nghi-quyet-77-NQ-CP-2014-thi-diem-doimoi-co-che-hoat-dong-co-so-giao-duc-dai-hoc-cong-lap-2014-2017-254531.aspx

Greenwood, R., Raynard, M., Kodeih, F., Micelotta, E. R., \& Lounsbury, M. (2011). Institutional complexity and organizational responses. Academy of Management Annals, 5(1), 317-371.

Jensen, M. C., \& Meckling, W. H. (1976). Theory of the firm: Managerial behavior, agency costs and ownership structure. Journal of Financial Economics, 3(4), 305-360.

Manz, C. C. (1986). Self-leadership: Toward an expanded theory of self-influence processes in organizations. Academy of Management Review, 11(3), 585-600.

Moe, T. M. (1984). The new economics of organization. American Journal of Political Science, 28(4), 739-777.

Olssen, M., \& Peters, M. A. (2005). Neoliberalism, higher education and the knowledge economy: From the free market to knowledge capitalism. Journal of Education Policy, 20(3), 313-345.

Senge, P. (1999). It's the learning: The real lesson of the quality movement. The Journal for Quality and Participation, 22(6), 34-40.

Thornton, P. H., Ocasio, W., \& Lounsbury, M. (2015). The institutional logics perspective. Emerging Trends in the Social and Behavioral Sciences, 1-22. doi:10.1002/9781118900772.etrds0187

Tilaar, H. A. R. (2012). Riset kebijakan Pendidikan Anak di Indonesia (hal. 237). Tangerang: Kementerian Pendidikan dan Kebudayaan UNICEF Indonesia. Retrieved March 10, 2021, from http://pustaka.unpad.ac.id/wp-content/uploads/2018/07/Abstrak-Teacher-Certificationin-Indonesia.pdf

Warsono, H. (2009). Networking dalam Intergovernmental Management. Dialogue Jurnal Ilmu Administrasi Publik, 6(1), 78-91.

Wiseman, R. M., Cuevas-Rodríguez, G., \& Gomez-Mejia, L. R. (2012). Towards a social theory of agency. Journal of Management Studies, 49(1), 202-222.

Zahra, S. A., Gedajlovic, E., Neubaum, D. O., \& Shulman, J. M. (2009). A typology of social entrepreneurs: Motives, search processes and ethical challenges. Journal of Business Venturing, 24(5), 519-532.

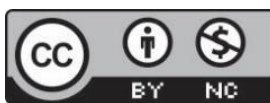

Creative Commons Attribution-NonCommercial 4.0 International License. 